\title{
Mutation spectrum of CYP21A2 and correlation between genotype - phenotype in 81 Vietnamese patients with congenital adrenal hyperplasia due to 21-hydroxylase defficiency
}

\author{
Vu Chi Dung ${ }^{1 *}$, Tran Van Khanh², Maki Fukami², Le Thi Phuong ${ }^{2}$, Nguyen Thi Ha², Nguyen Thanh Liem', \\ Ta Thanh Van ${ }^{2}$
}

From 7th APPES Biennial Scientific Meeting

Nusa Dua, Bali. 14-17 November 2012

Congenital adrenal hyperplasia $(\mathrm{CAH})$ is one of the most common inherited metabolic disorders. It includes a group of autosomal recessive disorders caused by the deficiency of one of the enzymes involed in one of the various steps of adrenal steroid synthesis. The most common form of CAH (95\%) is caused by mutations in $C Y P 21 A 2$, the gene encoding the adrenal steroid 21-hydroxylase enzyme (P450c21). Two major phenotype are recognized in 21-OHD: classic and non-classic. Classic $\mathrm{CAH}$ is clinically categorized in two groups: the simple-virilising and the salt-wasting form. The National Hospital of Pediatrics (NHP) in Hanoi is an 1100 bed tertiary referral centre servicing approximately 30 million people from northern provinces of Vietnam. At the start of 1999 there were 91 children with CAH due to 21-hydroxylase deficiency (21-OHD) managed at NHP. By June 2012 this increased to 624 [98.2\% due to 21-OHD], representing a more than six fold increase over 12 years. Number of new cases ranged from 40 to 70 per year.

We aim to determine the mutations in the CYP21A2 gene in Vietnamese patients with $\mathrm{CAH}$ and attempt a genotype-phenotype correlation. Molecular analysis was performed using PCR, multiplex ligation-dependent probe amplification and direct sequencing of PCR products of the CYP21A2 gene in $81 \mathrm{CAH}$ patients (39 male and 42 female). Correlation between phenotype and genotype was

'Vietnam National Hospital of Pediatrics, Hanoi, Vietnam

Full list of author information is available at the end of the article evaluated based on identified mutations and clinical manifestations.

Mutations were identified in $92.6 \%$ mutant alleles, 22 genotypes were found in 81 cases. Seven different causative mutations were identified in $C Y P 21 A 2$ including one novel mutation. The most frequent genetic defect in the classic salt-wasting and simple virilizing forms was the IVS2-13A/C>G (54 alleles; 36\%) mutation, followed by Large lesion (42 alleles; $28 \%$ ) including exon 1 deletion ( 2 alleles), exon 1-3 deletion (10 alleles), exon 1-6 deletion (4 alleles), exon 1-8 deletion ( 2 alleles) and larger deletion (24 alleles); p.R356W (26 alleles; $17.3 \%)$; p.1172N (15 alleles; 10\%). The rarer mutations were novel one p.R484fsX541 (6 alleles; 4\%); p.Q318X (4 alleles; $2.7 \%$ ) and p.R426C (3 alleles; $2 \%$ ). The majority of patients (61 cases; $75.3 \%$ ) were homozygotes. Four cases were compound heterozygous. Thirteen patients had only a heterozygous mutation detected. Genotype accurately predicted phenotype in 93.8 and $100 \%$ of patients with salt-wasting and simple virilizing, respectively.

The spectrum of mutations of the CYP21A2 gene in Vietnamese patients is comparable to the some reported in other Asian population. Large deletion accounts for nearly one-third of the genetic defects. Therefore, laboratory should include methods for detecting point mutations as well as large deletions. Genotype-Phenotype correlation was high in the studied patients.

(c) 2013 Dung et al; licensee BioMed Central Ltd. This is an Open Access article distributed under the terms of the Creative Commons 


\section{Authors' details}

${ }^{1}$ Vietnam National Hospital of Pediatrics, Hanoi, Vietnam. ${ }^{2}$ Hanoi Medical

University, Hanoi, Vietnam. ${ }^{3}$ National Research Institute for Child Health and

Development, Tokyo, Japan.

Published: 3 October 2013

doi:10.1186/1687-9856-2013-S1-P128

Cite this article as: Dung et al: Mutation spectrum of CYP21A2 and

correlation between genotype - phenotype in 81 Vietnamese patients with congenital adrenal hyperplasia due to 21 -hydroxylase defficiency.

International Journal of Pediatric Endocrinology 2013 2013(Suppl 1):P128.

Submit your next manuscript to BioMed Central and take full advantage of:

- Convenient online submission

- Thorough peer review

- No space constraints or color figure charges

- Immediate publication on acceptance

- Inclusion in PubMed, CAS, Scopus and Google Scholar

- Research which is freely available for redistribution

Submit your manuscript at www.biomedcentral.com/submit
C Biomed Central 